\title{
Strength and Dilation Behaviour of a Reconstituted Sand-Shell Mixture
}

\author{
Suleiman Khatrush ${ }^{1 *}$

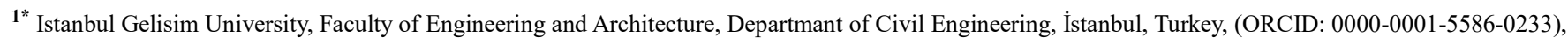 \\ sasmohamed@gelisim.edu.tr
}

(1st International Conference on Applied Engineering and Natural Sciences ICAENS 2021, November 1-3, 2021)

(DOI: 10.31590/ejosat.1011158)

ATIF/REFERENCE: Khatrush, S. (2021). Strength and Dilation Behaviour of a Reconstituted Sand-Shell Mixture. European Journal of Science and Technology, (28), 831-836.

\begin{abstract}
Calcareous sand usually composed of particles of carbonite origin of relatively weak structure, high void ratio and low grain strength. These sands show different strength and dilation behaviour than quartzite sands due to the existence of calcareous material. Several locations on the Libyan coasts are containing calcareous sands or sands with considerable amount of calcareous material such as broken shells or shell fragments. The present study is concerning in investigating the effect of the amount and the size of the calcareous material on the shear strength behaviour of sand shell mixtures. Samples were obtained from a coastal site near the city of Benghazi. The sand shell mixtures were prepared at practically similar unit weight and at a dense state. Two series of tests were performed in direct shear box of $100 \times 100 \mathrm{~mm}$ on reconstituted samples of dry sand, the first was mixed with proportions of 20,40 and $60 \%$ of broken shells by weight of material, and the second was mixed with only $20 \%$ of shell sizes ranging from $0.85 \mathrm{~mm}$ to $4.75 \mathrm{~mm}$. The results indicated generally increasing of the peak angle of shearing resistance $(\phi p)$ and reduction of dilation response of sand with increasing the amount and size of shell material. Furthermore, larger compression with increasing content and size of shell material is also observed due to the crushing of shell material during shearing.
\end{abstract}

Keywords: Sand; Calcareous material; Shear strength; Dilation; Direct shear.

\section{Sulandırılmış Kum Kabuk Karışımının Mukavemet ve Genleşme Davranışı}

$\ddot{O} z$

Genellikle nispeten küçük yapılı, yüksek boşluk oranına ve düşük tane mukavemetine sahip karbonit kökenli parçacıklardan oluşan kalkerli kum. Bu kumlar, kalkerli malzemenin varlığı nedeniyle kuvarsit kumlarından farklı mukavemet ve genleşme davranışı göstermektedir. Libya kıyılarındaki çeşitli konumlar, kırık kabuklar veya kabuk parçaları gibi önemli miktarda kalkerli malzeme içeren kalkerli kumlar veya kumlar içermektedir. Bu çalışma, kalkerli malzeme miktarının ve boyutunun kum kabuk karışımlarının kesme mukavemeti davranışı üzerindeki etkisini araştırmakla ilgilidir. Bingazi kenti yakınlarındaki bir kıyı bölgesinden örnekler alındı. Kum kabuk karışımları, pratik olarak benzer birim ağırlıkta ve yoğun halde hazırlanmıştır. Yeniden yapılandırılmış kuru kum numuneleri üzerinde 100x100 mm'lik doğrudan kesme kutusunda iki seri test yapıldı, ilki malzeme ağırlığına göre \%20,40 ve \%60 oranında kırık kabuk ile karıştırıldı ve ikincisi sadece \%20 ile karıştırıldı. 0,85 mm ile 4,75 mm arasında değişen kabuk boyutları. Sonuçlar, kabuk malzemesinin miktarı ve boyutunun artmasıyla genel olarak kesme direncinin tepe açısının ( $\phi p)$ arttığını ve kumun genleşme tepkisinin azaldığını göstermiş̧tir. Ayrıca, kesme sırasında kabuk malzemesinin ezilmesi nedeniyle, artan kabuk malzemesi içeriği ve boyutu ile daha büyük sıkıştırma da gözlenir.

Anahtar Kelimeler: Kum; Kalkerli malzeme; kesme mukavemeti; dilatasyon; Doğrudan kesme.

\footnotetext{
* Corresponding Author: $\underline{\text { sasmohamed@gelisim.edu.tr }}$
} 


\section{Introduction}

Calcareous sands or sands with a considerable content of calcareous materials and when its grains are of carbonite origin exhibit different behaviour than silica sands $[1,2,3]$. It is usually having a weaker structure, high void ratios and lower grain rigidity which make it susceptible to crashing during compression and shearing and even under relatively low pressures $[4,5,6]$. The crushing of particles may cause a reduction of shearing resistance $[4,6]$. On the other hand, oversized particles generally larger than the normal grading of the sand is expected to increase strength due to increasing particle interlocking during shear. [7, 8]. The existence of calcareous material within the sand has a significant effect on the estimation of parameters required for foundation design in such soils, especially frictional resistance of pile foundations and the interpretation of insitu test results such as standard penetration SPT and cone penetration CPT. The investigation of the behaviour of calcareous sands has received more attention in recent years [9, 10, 11]. Sands contains a considerable amount of calcareous material such as shell fragments of various sizes was found at Garyounis area near the south west coast of Benghazi city. The shell content is relatively fragile and easy to break with little effort. It is thought that such material could have a distinct effect on the engineering behaviour of sand. Therefore, it is aimed in this study to investigate the behaviour of a reconstituted sand-shell mixtures using different percentage of shell content and shell sizes and observing the effect on strength and dilation.

\section{Material and Method}

Samples of natural sand composed of calcareous materials and shell fragments were extracted from depths between 2 to $7 \mathrm{~m}$, at Garyounis area near Benghazi south west coast (Figure 1.), the samples contain variable sizes of shell fragments and the calcareous content of the samples are variable with depth. A Clean uniform beach sand free from calcareous material (Denoted here as $0 \%$ ) also obtained from the ground surface of the same area. The grain size distribution of a typical calcareous natural sand (Ns) and a clean beach sand is shown in Figure 2. The shells were obtained by separating them from a batch of natural sands and sizes larger than $4.75 \mathrm{~mm}$ were excluded to facilitate testing in small size shear box, whereas the rest were prepared by sieving to several desired sizes for mixing with the clean sand to provide a sand-shell mixtures required for the testing program. The first series of Sand - shell mixtures were prepared using a broken shell size of $(0.85-2.0 \mathrm{~mm})$ with $20 \%, 40 \%$ and $60 \%$ shell content by weight of the material. The second series were prepared with only $20 \%$ shell content and with the sizes; $(0.85-1.18 \mathrm{~mm}),(1.18-$ $2.0 \mathrm{~mm})$ and $(2.0-4.75 \mathrm{~mm})$.

A series of direct shear tests were conducted on samples of natural calcareous sand, clean sand and sand- shell mixtures. A shear box of dimensions $100 \times 100 \mathrm{~mm}$ is used throughout the testing program. For all testing samples an effort was made to keep the material unit weight of a convergent value and in a dense state, this was a difficult task, however it was achieved by taking a constant mass of the material and placed in the shear box in three layers tamping each layer by a fixed number of blows using a wooden tamper and rubber hammer until reaching the specified height of $50 \mathrm{~mm}$ every time. The resulting unit weight by this

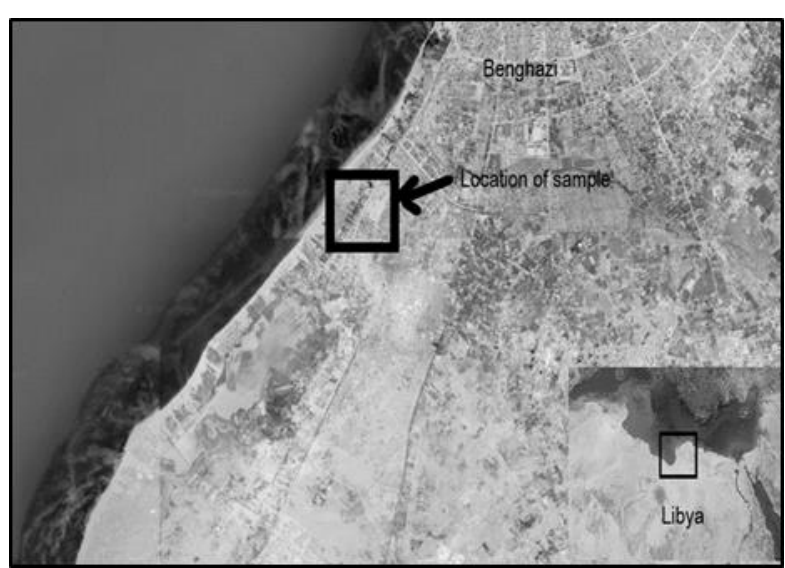

Figure 1. Location of samples collected (Benghazi, Libya, south west coast) coordinate $(23,02,30 N-20,01,23 E)$

method were kept within a range between 15 and $15.5 \mathrm{kN} / \mathrm{m} 3$. Three normal pressures 50,100 \& $200 \mathrm{kPa}$ were applied in every test before shearing. All the tested samples were sheared at a constant strain rate of $0.24 \mathrm{~mm} /$ minute and measurements of shear force, vertical and horizontal displacement were recorded at convenient intervals.

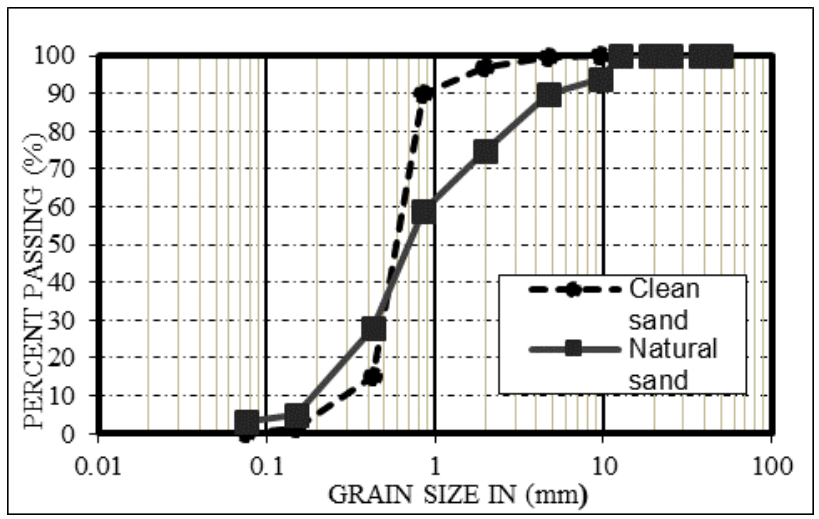

Figure 2. Particle size distribution for clean sand and calcareous sand.

\section{Results}

\subsection{Shear Strength}

The test on a clean beach sand sample is considered as a base reference to observe any subsequent effect triggered by the existence of the fraction and size of broken shells. Fig. 3 shows the resulting shear stress and vertical displacement against horizontal displacement for a tested sample of clean beach sand and a typical sample of natural calcareous sand tested after excluding larger shell sizes exceeding $4.75 \mathrm{~mm}$. The results shown in Figure 3. indicate higher peak strength values for calcareous sand compared with that for a clean sand shown in Figure 3. The behaviour, however, illustrates the significant contribution of calcareous material in the development of larger interlocking and hence, increases the frictional resistance at the shearing surface of the sample.

The dilative behaviour beginning with small compression increased with higher normal pressures, the calcareous sand sample is exhibiting larger compression before dilation compared with what happened in case of clean sand which referred to the 
susceptibility of calcareous material to be compressed and crush during shearing especially at higher normal stresses.

The peak shear stress is plotted against the normal pressure in Figure 4, The peak friction angle obtained for clean sand $(0 \%)$ and natural calcareous sand (NS) were (35.2o) and (41.1o) respectively.

\subsection{Effect of shell content}

The effect of shell content was considered by testing samples of sand-shell mixtures with different percentages by weight of $20 \%, 40 \%$, and $60 \%$, keeping one size of broken shells $(0.85-$ $1.18 \mathrm{~mm}$ ) in every test. The relationship between the peak shear stress and normal stress (i.e. Failure envelope) is plotted in Figure 5. for all proportions of shell contents together with that for clean sand. The slope of the approximated straight line however is representing the peak angle of shearing resistance $\left(\phi_{\mathrm{p}}\right)$. It can be seen that the peak resistance for samples with shell contents $40 \%$ and $60 \%$ is higher than that for clean sand while show lower strength for samples with shell content of $20 \%$. This is because the shell fraction of $20 \%$ is comparatively small and with size range nearly matching the clean sand average particles size but of weaker particle strength.

(a)

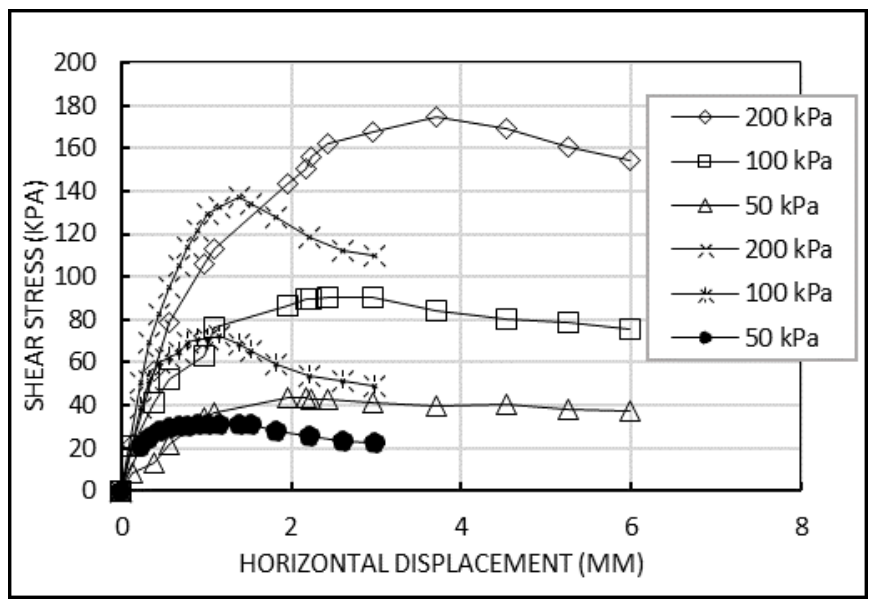

(b)

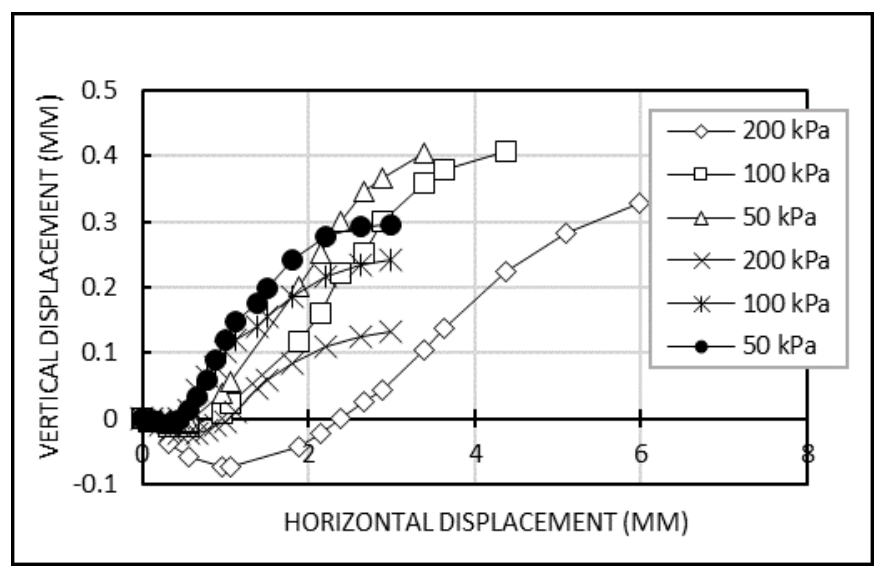

Figure 3. Test results on clean beach sand and natural calcareous sample (a) shear stress (b) vertical displacement

This obviously not expected to contribute in developing the shearing resistance, however, it was reported, elsewhere that $10 \%$ of shell content has no effect on shear strength [4]. Nonetheless, the value of $\left(\phi_{\mathrm{p}}\right)$ is not increased when shell content exceeding
$40 \%$, this is may be attributed to the interlocking resistance of the mixture is reaches a threshold value so that any further increase on shell content would have no effect on strength. The percentage of shell content above such limit could possibly provide larger mass of weak shell particles subjected to crushing during shear. The particle breakage causes more abrasion which led to less asperities of the sand particles, less interlocking and more particle arrangement and rotation [6].

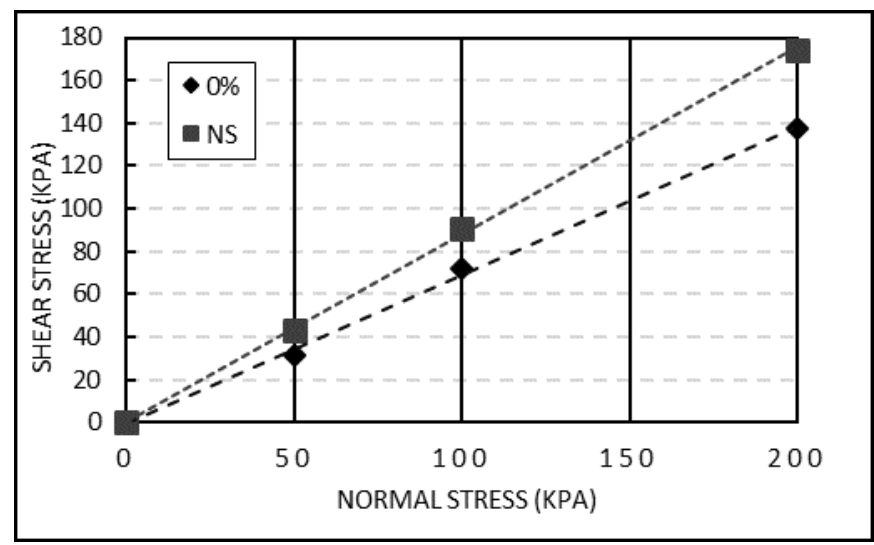

Figure 4. Failure envelope for clean sand (0\%) and natural calcareous sand (Ns)

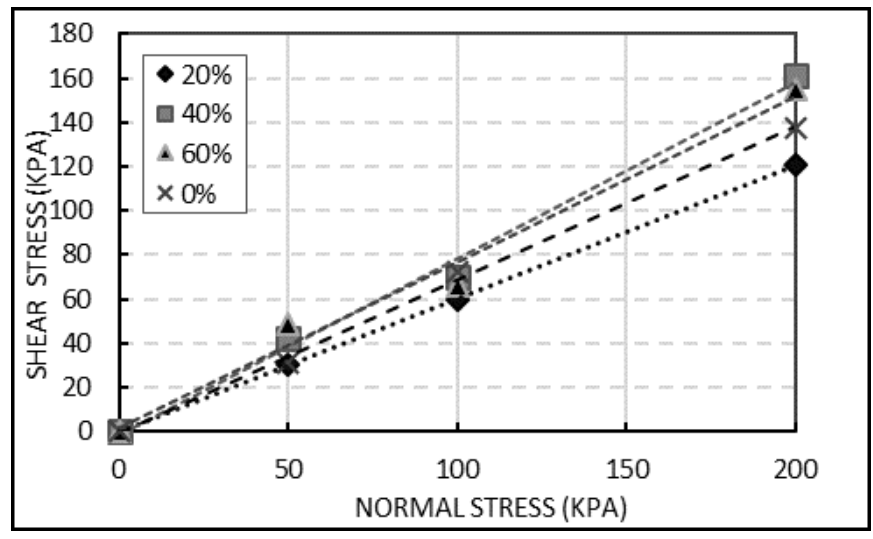

Figure 5. Effect of percentage of shells on the failure envelope

\subsection{Effect of shell size}

The effect of shell size is investigated using a mixture containing only $20 \%$ shell content with three different size ranges (0.85-1.18mm), (1.18-2.0mm) and (2.0-4.75). The results of peak shear stress against the normal stress is (i.e. Failure envelope) shown in Figure 6, in which the Slope is representing the peak angle of shearing resistance $\left(\phi_{p}\right)$ is generally getting higher with increasing size range, however when comparing with that of clean sand the peak shearing resistance of size range $(0.85-1.18 \mathrm{~mm})$, it is of lower peak strength than that of clean sand. This results indicate the significant effect of the size of shell content exist in the mixture provided their size range is larger than the average size of the clean sand medium. The larger sizes can significantly increase the particle interlocking during shearing despite the relative weakness of shell material. However, for calcareous sand the increase in the particle size leads to the growth of shear strength properties [8] and similarly, the existence of oversize 
particles within the sand and large average grading of sand tend to develop the shearing resistance $[4,6]$.

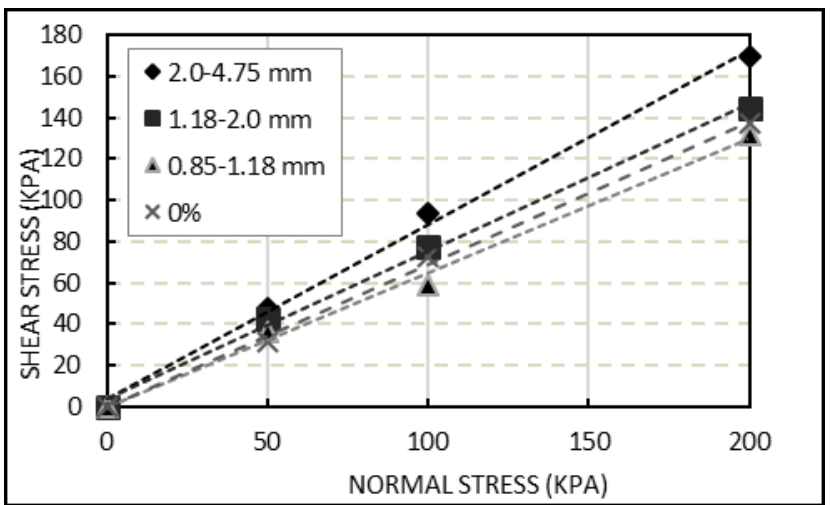

Figure 6. Effect Size range of shells on the failure envelope

\subsection{Dilation}

The dilation behaviour of the tested materials is represented by the maximum angle of dilation $\psi$ max which can be taken as the rate of change of vertical displacement (v) with the horizontal displacement (h) of the tested sample as; -

$$
\tan \psi_{\text {max }}=d v / d h
$$

The plots of the maximum angle of dilation against the applied normal pressure are shown in Figure 7. a, b \& c. The Trend is generally similar, hence the value of $\psi_{\max }$ is generally decreasing with increasing of normal pressure. Furthermore, it is seen that the values of $\psi$ max for clean sand is mostly higher than that of natural calcareous sand and sand-shell mixture despite the amount of shell content and size indicate that sands with weak structure or fragile grains exhibits low dilation. The angle $\psi$ max, however is approaching closer values for most of test results at normal pressure of $200 \mathrm{kPa}$.

\section{Discussion}

The results presented earlier in Fig 7 show that, the maximum angle of dilation $\psi$ max is suppressed by the increase of normal stress. It is also demonstrating that the $\psi_{\max }$ is influenced by both the percent increase of calcareous material and its size range.

Bolton [12] examined the dilation behaviour of several sands worldwide tested in plain strain condition and proposed an empirical relationship relating the angle of shearing resistance $\phi$, friction angle at constant volume $\phi_{\mathrm{cv}}$ and the dilation angle $\psi \mathrm{as}$;

$$
\phi_{\max }^{\prime}=\phi_{\mathrm{cv}}^{\prime}+0.8 \psi
$$

(a)

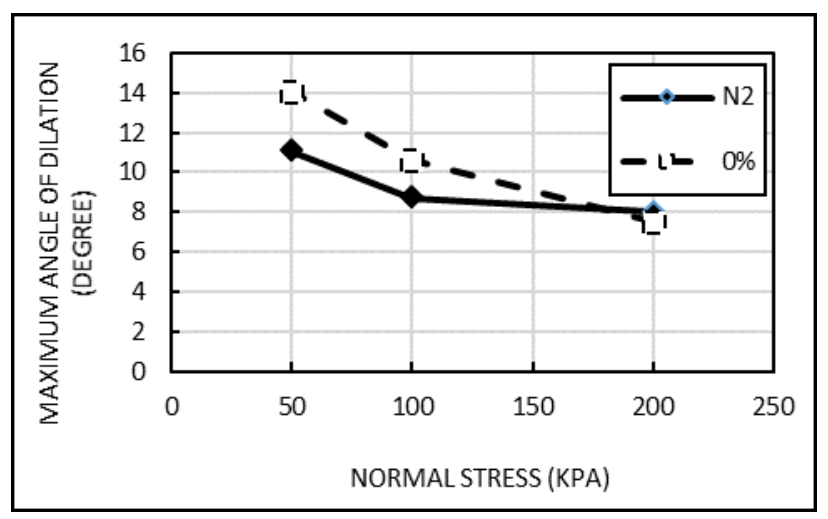

(b)

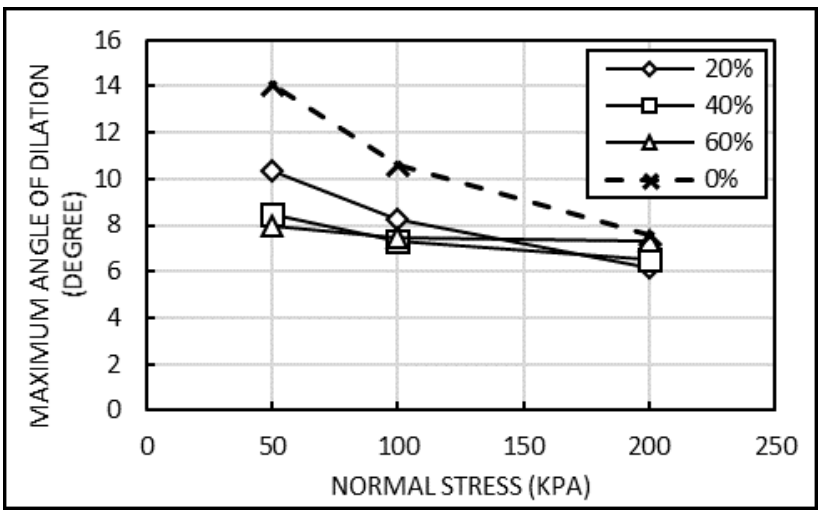

(c)

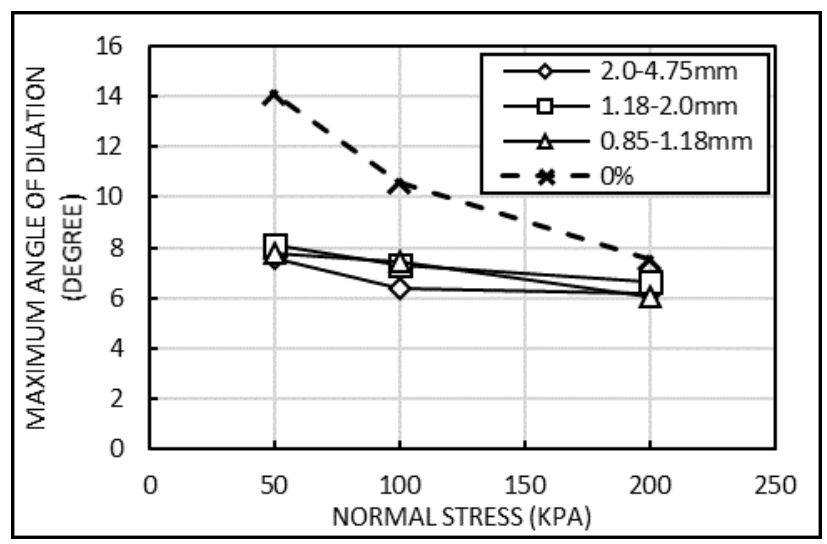

Figure 7. Variation of maximum angle of dilation with normal stress (a) clean sand (0\%), (b) Various percentage of sand-shell mixture, (c)Various size range of shells

Simoni and Houlsby [13], Raju and Nivya [14] suggested that Bolton's equation can also be adopted for the direct shear condition as;

$$
\varphi_{p}^{\prime}=\varphi_{c v}^{\prime}+b \psi_{\max }
$$

Where the $\varphi_{\mathrm{p}}^{\prime}, \varphi_{\mathrm{cv}}^{\prime}$ and $\psi \max$ are the angle of friction at peak stress value, the angle of friction at constant volume and the angle at a maximum rate of dilation respectively measured in the direct shear test and $\mathrm{b}$ is a constant similar to that proposed by Bolton 
[12] to be equals to 0.8 . Simoni and Houlsby [13] reported values of $b$ slightly different than 0.8 as the percentage of larger size gravel within the sand sample is increased.

It is rather difficult to correctly determine the value of the parameter $\varphi_{c v}^{\prime}$ on a limited size direct shear test because of the relatively high strain required to reach the critical state which should also corresponds to the point of zero rate of dilation or constant volume. However, by plotting the stress ratio $(T / \sigma)$ against horizontal displacement for both Natural calcareous sand and clean beach sand as shown in Figure 8, it indicates that the ultimate angle of friction $\varphi_{r}^{\prime}$ is not reaching the critical state and similarly for all other tests. Therefore, in order to examine the applicability of Bolton's equation for the case of shell- sand mixtures and for the sake of comparison, the amount of dilation exhibited during testing is estimated as the difference between the peak angle of shearing resistance $\varphi_{p}^{\prime}$ and the ultimate angle of friction $\varphi_{r}^{\prime}$ as it was measured during tests which arbitrary assumed to approximately equals to the critical state angle $\left(\varphi_{\mathrm{cv}}^{\prime}\right.$ ) .

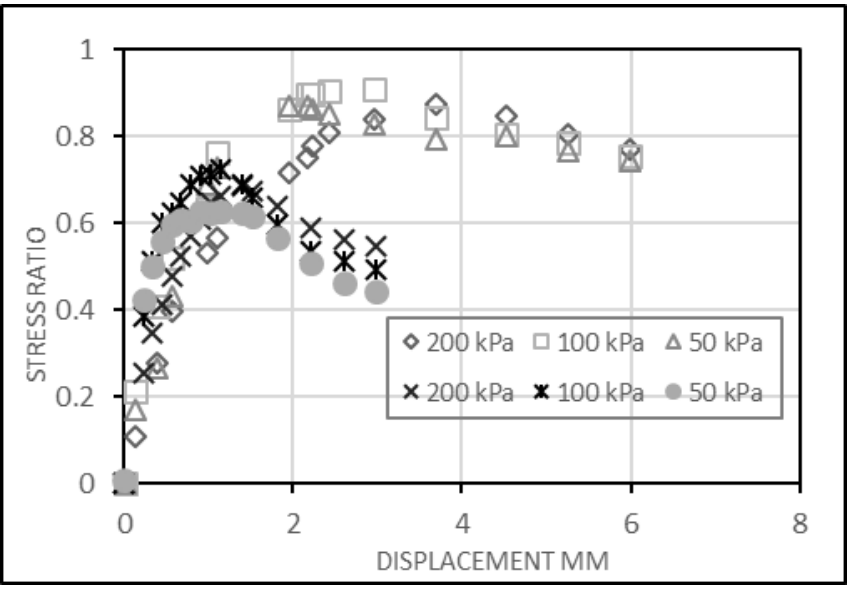

Figure 8. Stress ratio (T/ $\sigma$ ) against horizontal displacement for (a) Natural calcareous sand (b) clean beach sand.

The effect of normal stress on the dilation behaviour is presented in Figure 9.a,b for various percentage and size of calcareous material and compared with both clean sand $0 \%$ and natural calcareous sand Ns. The results show a reduction of the dilation rate with the increase of normal stress.

(a)

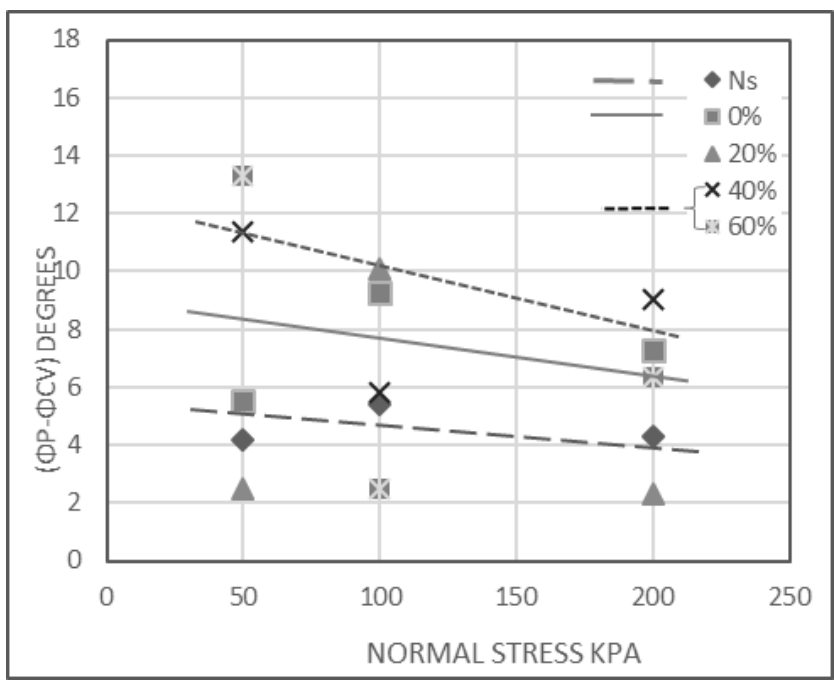

(b)

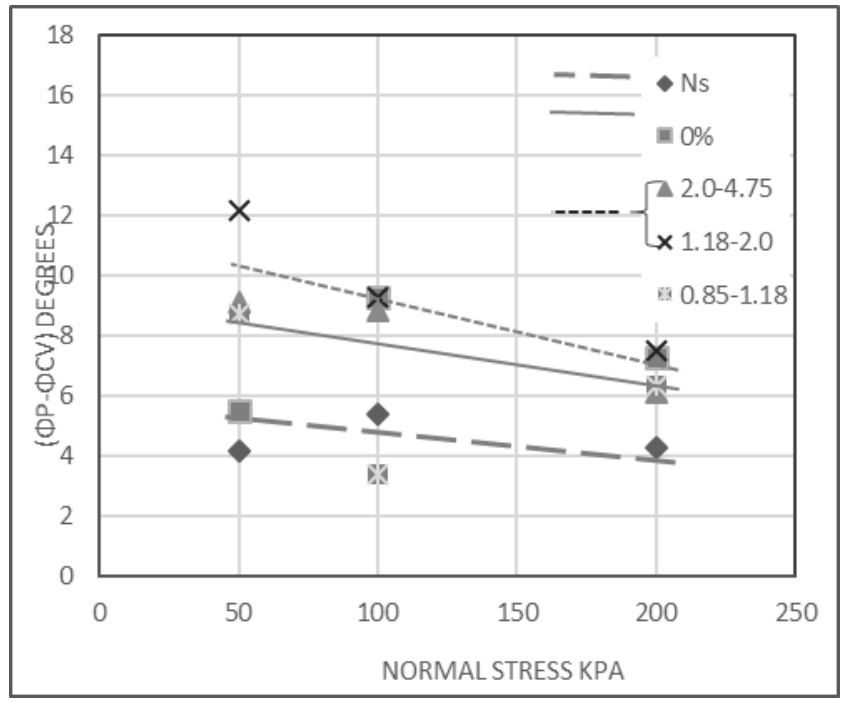

Figure 9. Dilation rate against normal stress (a) percentage of shells (b) Size range of shells

The general trend of the results is seemingly compatible with the findings of Bolton [12], this is more pronounced in case of clean sand $0 \%$ and natural calcareous sand Ns even though the later shows much lower dilation. It is also reported by Pei Cao et al [15], that the dilatation tendency decrease with increasing particle size and effective confining pressure. The results obtained from tests on samples of reconstituted mixture do not show clearly similar behaviour but a general increase of dilation rate $\left(\varphi_{\mathrm{p}}^{\prime}-\varphi_{\mathrm{cv}}^{\prime}\right)$ with the increase of both the amount and size of the calcareous material which is attributed to the increase of peak angle of friction corresponding to the decrease in the angle of dilation. Bolton's equation was found applied here for clean beach sand for the corresponding relative density used in the present study as presented in Figure 10.a,b. The constant $\mathrm{b}$ suggested by Bolton as 0.8 is reasonably fit for clean beach sand with $b$ of 0.75 and with lower value of $b$ of 0.5 for natural calcareous sand, but in contrary, for the reconstituted sand mixtures is showing greater values than 0.8 which may exceed (1.0) as the size or the amount of calcareous material is increased. This may not correctly represent the behaviour of a calcareous sand which supposedly be with lower value of the constant $b$, but it can be related to the inaccurate estimation of $\varphi_{\mathrm{cv}}^{\prime}$.

(a)

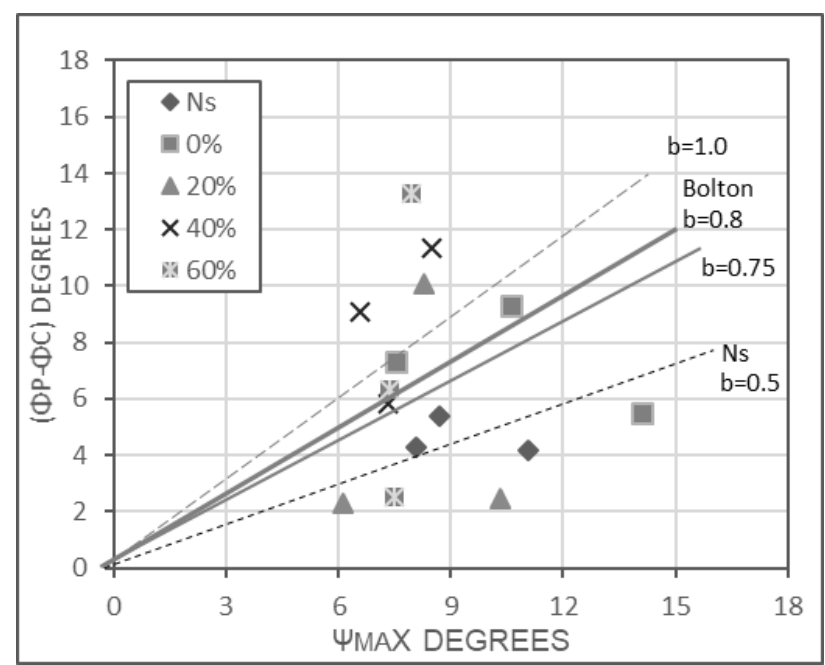


(b)

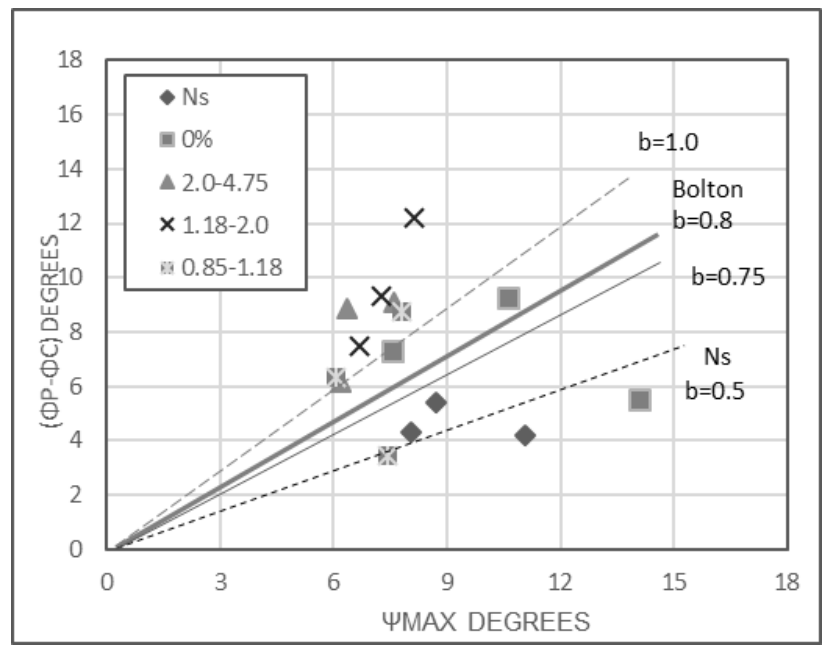

Figure 10. Dilation rate against $\psi$ max (a) percentage of shells (b) Size range of shells.

The results indicated that the behaviour of calcareous sand which is mostly or completely of carbonate origin cannot thoroughly be simulated by an artificial mixture which is partially consisted of silica sand, basically the effect of particle grading and particle strength have a very significant role on their behaviour. Nevertheless, the results presented in this study were able to qualitatively demonstrate the relative change of strength and dilation behaviour with the variation of calcareous material existing within the sand mass.

\section{Conclusions}

Based on a series of direct shear tests on clean beach sand and reconstituted sand-shell mixture with various proportions and sizes, it is observed that:

- The peak angle of shearing resistance $(\phi p)$ is higher for natural calcareous sand sample than that for clean beach sand. However natural sand exhibits larger compression and lower dilation.

- Shearing resistance for sand - shell mixture is generally increasing with increasing shell content above $20 \%$, whereas, exhibiting lower dilation

- sand-shell mixture with shell sizes generally larger than average sand sizes show higher peak friction resistance accompanied with lower dilation

- The susceptibility of particle breakage of calcareous material within the sand-shell mixture is significantly affecting the resulting behaviour.

- The results show that the equation suggested by Bolton to describe the dilation behaviour of quartz sands is generally not applicable for the reconstituted sand - shell mixture.

\section{Acknowledgment}

The experimental work was conducted in the soil mechanics laboratory, faculty of engineering, University of Garyounis, Benghazi Libya. The author wish to express his sencier thanks to the soil mechanics laboratory staff who were assesting in collecting the samples and testing.

\section{References}

[1] Van Impe, W.F, Menotti, A., Menge, P., VandenBroeck, M., Vinck, K. (2015). Compaction control and related stressstrain behaviour of off-shore land reclamations with calcareous sands, Soils and Foundations; Vol 55 No. (6) pp1474-1486.

[2] Abdeltawab S., EL Mashad M. and El Shinawi A. (2013). "Geoengineering Properties of calcareous and Quartzite sand collected from West Alexandria coastal line and Abo Rawash Quarry area. "International Journal of Scientific \& Engineering Research, Volume 4, Issue 11, 934

[3] Safinus, S., Hossain, M.S., Randolph, M.F.(2013) Comparison of stress-strain behaviour of carbonate and silicate sediments , Proc. 18th Int. Conf. On Soil Mechanics and Geotechnical Engineering, pp. 267-270.

[4] Ata A., Salem T. N., Hassan R. (2018) Geotechnical characterization of the calcareous sand in northern coast of Egypt, Ain Shams Engineering Journal, 9, 3381-3390.

[5] Hassanlourad M., Salehzadeh H., Shahnazari H. (2008) Dilation and particle breakage effects on the shear strength of calcareous sands based on energy aspects "International Journal of Civil Engineerng. Vol. 6, No. 2. 108-119

[6] Al Hattamleh O.H., Al-Deeky H.H. \&. Akhtar M.N. (2013) The Consequence of Particle Crushing in Engineering Properties of Granular Materials,International Journal of Geosciences 04(07), 1055-1060M.

[7] Lim, M. S., Wijeyesekera D. C., Zainorabidin A.\& Bakar I. (2012) The Effects of Particle Morphology (Shape and Sizes) Characteristics on its Engineering Behaviour and Sustainable Engineering Performance of Sand, International Journal of Integrated Engineering, Vol. 4, No. 4, pp. 27-37

[8] Giang P.H.H., Van Impe P. O., Van Impe W. F., Menge P., Cnudde V., Haegeman W. (2017) Effects of particle characteristics on shear strength of calcareous sand, Acta geotechnica Slovenica 14(2).

[9] Carter, J.P., Airey, D.W. and Fahey, M., (1999). A review of laboratory testing of calcareous soils, Proc., The Second International Conference on Engineering for Calcareous Sediments, Bahrain, 21-24 .

[10] Elkateb T.M., Ali H.E. (2010), CPT-SPT correlations for calcareous sand in the Persian Gulf area ",2nd International Symposium on Cone Penetration Testing, Huntington Beach, CA, USA.

[11] Yasufuku N, Hyde A.F.L. (1995) Pile end-bearing capacity in crushable sand. Geotechnique;45(4):663-76.

[12] Bolton, M.D. (1986) The strength and dilatancy of sands Géotechnique., 36(1),65-78,

[13] Simoni, A. and Houlsby, G.T. (2006) The direct shear strength and dilatancy of sand-gravel mixtures." Geotech. and Geol. Engrg., 24(3), 523-549.

[14] K.V.S.B. Raju and Nivya E.C. (2017) Strength and Dilatancy of Granular Materials International Journal of Research and Scientific Innovation (IJRSI) | Volume IV, Issue X, October, 2321-2705

[15] Pei Cao , Ming-jing JIANG and Zhi-jun DING, (2020) Effects of particle size on mechanical behaviors of calcareous sand under triaxial conditions, 8th Japan-China Geotechnical Symposium, Japanese Geotechnical Society Special Publication, Volume 8 , Issue 5, , 182-187. 